\title{
Forcing Morals on Mesopotamian Society?
}

\author{
JACK M. SASSON
}

Nashville

Until recently the title of Sarah Pomeroy's venerable book, Goddesses, Whores, Wives, and Slaves just about covered the range of roles we have allotted to women from ancient Mesopotamia. ${ }^{1}$ Certainly we have discriminated among women by whether they were humans or deities, queens or commoners, secular or priestly, native or foreigners, sequestered or unfettered, wives or spinsters, mothers or barren, sexually available or not. Occasionally, we have even assigned one personality a mix from among the above roles. (We had a great time with an Inanna, a Nefertiti, or a Jezebel.) Generally, however, we were satisfied that these roles were not shaped by lack of imagination or allegiance to myopic methodologies, but bolstered by our inspection of artifacts and documents, all painstakingly assembled, analyzed, and classified.

Above all, we have relied on a diversity of materials to give moorings to our reconstructions. Mesopotamian narratives and other literary documents (love songs, hymns, wisdom texts, even when authored by a largely male scribal culture) have displayed women as major participants in public spheres. Letters written by and to women have given them distinct voices and personalities. And recovered artifacts have established how extensively women-oriented were the products of ancient economies (clothing, utensils, decorations, etc).

Nevertheless, whenever called on to shape a profile for the Mesopotamian woman - the privileges she enjoyed, the obstacles she met, and the limitations she faced-we have privileged a singularly unrealistic genre of written material, the legal compilations produced by scribes over two millennia of social history. Moreover, we seem to gravitate toward a moral explanation of individual legal stipulations whenever sexual matters are at stake, thus indulging

Author's note: Brief though it may be, this paper allowed me to conduct fruitful discussions with R. Harris, M. Roth, M. Stol, and R. Westbrook, for which I am very grateful.

1. Sarah B. Pomeroy, Goddesses, Whores, Wives, and Slaves: Women in Classical Antiquity, with a new preface by the author (New York, 1995). 
our inclination toward melioristic interpretion of juridical documents. ${ }^{2}$ This brief paper will focus on one text, BM 13912, to explore potential avenues for recreating the contexts behind its composition. I dedicate it to Harry Hoffner, a teacher, a friend, and a sensitive reader of Hittite legal formulations and of the culture that produced them.

Moshe Anbar edited BM 13912, copying, translating, and lightly annotating it in an issue of $R A .{ }^{3}$ The text was featured in a study by $\mathrm{R}$. Westbrook on "The Enforcement of Morals in Mesopotamia" and was cited by Martha Roth in a study of adultery and its consequences in the Neo-Babylonian period. ${ }^{4}$ Westbrook faulted Anbar's reading of the document and offered a revised translation of it. Normalized and displayed in paragraphs, the Akkadian of our document reads as follows:

1. Šat-Marduk aššum Ahuni mär llšu-ibbi nī̌s Samsu-ilunu lugal kĩam itma umma šima

5. ana Ahuni mār Ilšu-ibbi la kalâkšu la tummakšumma la iturru ša zikarim u sinništim la iqabbiamma šaptìya la inaššiquma ša zikarim u sinništim la amaggarušma

10. ana utūl sūni liqrianni šìūt ālim u rabiānam lū ušeddi

13. ina ahitim immarūninnima kima nīš šarrim utappilu lū ipušūninni

16. u Ahuni mār Ilšu-ibbi niš Samsu-iluna lugal kiam itma umma šūma

19. ana Šat-Marduk la allakuma ša zikarim u sinništim la aqabbušimma

Paying some attention to the coordinating distribution of the particle -ma suggests the following rendering:

About Ahuni, son of Ilšu-ibbi, Šat-Marduk swore as follows by King Samsu-iluna,

5"Pertaining to Ahuni, son of Ilšu-ibbi: (I swear that) I am not detaining him. (I swear that) I am not bound to him by oath, therefore he must not come back. He must not talk to me about sexual intimacy; he must not kiss my lips nor shall I accord him sexual intimacy."

10"Should he summon me to sleep with him, (I swear that) I will inform the city elders and the 'mayor.' If I am found with him (or: in the countryside), I should be treated as if I broke an oath by the king."

2. See the criticism of Martha Roth on the history of interpreting "The Priestess and the Tavern: LH \$110," in Munuscula Mesopotamica: Festschrift für Johannes Renger, ed. Barbara Böck et al. (Münster, 1999), 445-63.

3. Moshé Anbar (Bernstein), "Textes de l'époque babylonienne ancienne," $R A 69$ (1975): $120-25$.

4. R. Westbrook, "The Enforcement of Morals in Mesopotamia," JAOS 104 (1984): 753-56; M. Roth, " 'She Will Die by the Iron Dagger.' Adultery and Neo-Babylonian Marriage," JESHO 31 (1988): 193 n. 14. 
${ }^{16} \mathrm{Ahuni}$, son of Ilšu-ibbi, then swore as follows by King Samsu-iluna, "(I swear that) I will not go to Sat-Marduk and (that) I will not talk to her about sexual intimacy." 5

Westbrook disputes Anbar's opinion that the text records a public declaration by a married couple wishing to separate. He points out that the document says nothing about a marital state and that its stipulations avoid issues regarding marital property, focusing instead exclusively on sexual matters. Moreover, a judicially anointed separation-rather than a complete divorceis an alien concept in Mesopotamian law. In all this Westbrook is undoubtedly correct, and Roth, who knew his study, agrees that this document is not about an enforced separation.

Yet in reconstructing a context for BM 13912 Westbrook hinged his solutions on information not delivered by the text under inspection. ${ }^{6}$ In his opinion, the text illustrates a prohibition found in paragraph 30 of the Lipit-Ishtar legal compilation (LL). While specialists have offered decidedly different renderings for the initial clause of this law, for argument's sake I quote Westbrook's own version:

If a prostitute from the street holds a young married man (guruš) and the judges forbid him to return to that prostitute, (if) after he divorces his wife, (even) if he has paid divorce money, he shall not marry this prostitute. ${ }^{7}$

5. It might be useful to present the translations of Anbar and Westbrook:

Anbar: "Šat-Marduk à cause d'Ahūni fils d'Ilšu-ibbi (par) la vie de Samsu-lluna, le roi, ainsi a juré, en disant: 'Quant à Abūni fils d'Ilšu-ibbi je ne le retiens pas, je ne suis pas liée à lui par serment, qu'il ne revienne pas, qu'il ne me propose pas de relations conjugales et qu'il n'embrasse pas mes lèvres: je ne lui accorderai pas de relations conjugales, et s'il m'appelle pour coucher dans (mon) sein, aux anciens de la villes et au maire je (le) ferai savoir! Si on me voit dans les environs, comme j'ai méprisé (le serment par) la vie du roi, [qu'on] me traite.' [Et] Abūni fils d'Ilšru-ibbi [(par) la vie] de Samsu-iluna, le roi, [ains]i a juré, en disant: 'Quant a Šat-Marduk je n'irai pas et je ne lui proposerai pas de relations conjugales: ..."

Westbrook: "In the matter of Ahuni son of Ilshu-ibbi, Sat-Marduk swore the oath of King Samsu-iluna thus, saying: 'As for Ahuni son of Ilshu-ibbi, I do not hold him, I am not sworn to him; He shall not again propose sexual relations to me, he shall not kiss my lips. I will not accord him sexual relations; If he calls me for lying in the lap, I will verily inform the city elders and the mayor. If I am seen in (his) company, let them treat me as if I had disregarded the oath of the king.' And Ahuni son of Ilshu-ibbi swore the oath of King Samsu-iluna thus, saying, "I shall indeed not go to Sat-Marduk and propose sexual relations to her." "

6. Westbrook's conclusions are supported by Sophie Lafont, Femmes, Droit et Justice dans l'antiquité orientale (Fribourg, 1999), 29-30, and by D. Charpin, who also offers his own translation of the text, in Rendre la justice en Mésopotamie, ed. F. Joannès (Vincennes, 2000), 95-96 (no. 51).

7. M. Roth's rendering of LL 30 reads: "If a young married man has sexual relations with a prostitute from the street, and the judges order him not to go back to the prostitute (and if) afterwards he divorces his first-ranking wife and gives the silver of her divorce settlement to her, (still) he will not marry the prostitute"; Law Collections from Mesopotamia and Asia Minor (Atlanta, 
However we read LL 30, there is no denying that the law could block a person from marrying a prostitute with whom he had been consorting. It is not clear however, that enforcement of morals was its goal. ${ }^{8}$ Consorting with prostitutes, even during marriage, was not legally censured for an adult male, and at any rate LL 30 does not prevent the man involved with a prostitute from divorcing his wife. What seems crucial here is the youth of the married man, for gurus is an exceptional designation for a male in LL. It may well be that this language implies that the parents of the husband are still in control of his fate, possibly inviting the interference of judges to deny any patrimony to children that a prostitute might attribute to the young man. And while we may imagine discomfort in having a prostitute as a wife, because she would not devote herself sexually to a single individual, the fact remains that prostitutes were not legally thwarted from marital life, whether as concubines or even as primary wives.

Returning to BM 13912, we notice that Šat-Marduk is nowhere stated to be a prostitute, even if the town's worthies seem on first inspection to be forcing their will on her. Second, while Sat-Marduk is enjoined not to be seen in Ahuni's company, the oaths they each take agree that Ahuni is the potential initiator of sexual contact. Moreover, unlike the prostitute of LL 30 (in Westbrook's translation), Sat-Marduk can assert under oath that she is not detaining Ahuni. ${ }^{9}$ Most obvious too is that BM 13912 says nothing about Ahuni's marital status, forcing us to keep open the possibility that there might not have been a Mrs. Ahuni to betray sexually or protect. Moreover, nothing about Ahuni's age is revealed, so we cannot know whether LL 30, with its specific reference to the youth of the married man (guruš), applies to him. We recall that LL 27 does permit a man to raise a child from a prostitute should his own wife fail to bear. ${ }^{10}$

1995), 32. Westbrook gives a rendering that closely matches the above in his Old Babylonian Marriage Law. AfO Beiheft 23 (Horn, Austria, 1988), 75 n. 45. However, he recently wrote to me (1/27/2000): "As regards LL 30, in AfO [Beiheft] I had forgotten my earlier study and was following the consensus. But unless someone can explain the grammar otherwise to me, I still consider my JAOS version to be the better one."

8. It is interesting that under the rubric "Moral," the Reallexikon der Assyriologie 8, 377, refers readers to such entries as "Eid," "Eigentum," "Familie," and "Geschlechtsmoral," but decides not to devote an entry to the issue itself.

9. Westbrook reads lines 5-6 as promissory on Ahuni's part to marry a prostitute, unnecessarily complicating a scenario that already is missing a wronged wife. In the same way, his rendering of the protasis of $L L 30$, which he defends in note 4 of his study, gives the prostitute an active role in a drama that is, by his own admission, "obscure."

10. ana ittišs (MSL I) VII ii 23-25 speaks of a man marrying a prostitute (kar.kid, harimtu) from the public square; iii 7-11 refers to a divorced man wishing to marry a nu.gig (qadištu) from the street $($ sila $=s \bar{q} q u m$ ), who had adopted a child of the street. (See also the lexical notes to the $C A D$ entries harimtu and qadištu.) 
Westbrook was of course aware of this last discrepancy. ${ }^{11}$ But to explain "why the man should be prohibited from consorting with a prostitute if he were not," Westbrook invoked a juridical text from Ur of the Kassite period (UET 7/1.8):

Sin-erimanni, son of Sin-rimanni, married the daughter of Gula-eriš, a herdsman for the district governor; but Ilatu, daughter of Arkaya, detained her for ... [ [ana naptarüti $\left.{ }^{12}\right]$, forcing him to leave his wife. Sin-bēl-tabīni, his brother, summoned Ilatu before Sin-šapik-zeri, the judge, saying, "she made (her) abandon my brother Sin-rimanni."

${ }^{10}$ The judge posed a question to Ilatu, saying, "why did you make (her) abandon Sin-rimanni, the herdsman?" On hearing the judge's word, she said, "Sin-rimanni, servant of my lord, until just now has been sleeping with me. Since my lord has interrogated me, he won't come by the rim of my bed!"

rev. ${ }^{3}$ If Sin-rimanni once more enters the house of Ilatu, whether to relax during daytime or to stay overnight, he should be arrested, investigated, and questioned, as per Sin-šapik-zeri's decree. ${ }^{13}$

Here, no less than in BM 19312, to make a prostitute out of Ilatu we must read LL 30 into the text. ${ }^{14}$ In fact, there is little to make us suppose Ilatu was a common prostitute: she is identified by a patronymic and can detain a married woman for a purpose that still escapes us. Moreover, the judge is treating this alleged prostitute very gingerly. She is given the opportunity to explain her connection and, upon volunteering to end it, she incurs none of the dreaded punishments diverse Mesopotamian collections of laws predict

11. "The missing element in the above source is the cuckolded wife, which leaves some doubt as to whether the man was in fact married ..." ("Enforcement of Morals," 755).

12. Westbrook's study suggests a translation "for a visit" or for "temporary accommodation," which does not seem to fit well in this context; "The Old Babylonian Term naptarum," JCS 46 (1994): 41-46.

13. Oliver Gurney, The Middle Babylonian Legal and Economic Texts from Ur (Oxford, 1983), 43-45. Gurney had featured this text in "A Case of Conjugal Desertion," in Zikir sumim. Assyriological Studies Presented to F. R. Kraus on the Occasion of his Seventieth Birthday, ed. G. van Driel et al. (Leiden, 1982), 91-94. See also C. Wilcke, “šumșulum, 'den Tag verbringen,"' ZA 70 (1980): 138-40. In his article, Westbrook reports on their opinions and offers a rendering that differs from mine in ways not immediately crucial to the present discussion.

UET $7 / 1.8$ is witnessed by, among others, the mayor and a diviner. It is dated to $D u^{\prime} u z u 22$, Adad-shuma-ușur 12 (ca. 1203 в.c.).

14. Quoting Westbrook ("Enforcement of Morals," 756), "It is not stated that the woman is a prostitute, but the fact that [the married man] continued to cohabit with her without marrying her is suggestive of her status, as is perhaps the explicit nature of the woman's statement to the court on her relations with him." 
for home-wreckers. ${ }^{15}$ It is not even clear that the matter has anything to do with saving a marriage. In fact, the text is altogether unsettling, for the person about whom the case is being brought is not the husband of the nameless woman, a man named Sin-erimanni, but her father-in-law, Sin-rimanni. Moreover, the judge refers to the abandoned man as a "herdsman," the title conferred on the woman's father, Gula-eriš, so neither her husband nor her father-in-law. To make sense of this murky situation, either we must imagine confusions galore on the part of the scribe no less than the judge, or take up the writing of kinky fiction.

We need also to notice that rather than Ilatu bearing the brunt of accountability, the onus instead is placed on Sin-rimanni, requiring him to avoid Ilatu's presence lest he be dragged before the authorities. Nothing is said about Ilatu being forced to release Sin-erimanni's wife. All in all, we get the impression of a messy situation, and we might imagine that no one was particularly grateful to the busybody brother, Sin-bēl-tabini, for dragging so many people to court.

If it cannot be shown that Old Babylonian BM 13912 illustrates a community's enforcement of marital morals, what facet of Mesopotamian social life does it illumine? Certainly we are limited by the lack of details on the circumstances that led to its drafting. The document records two oaths by personalities not easy to identify from other sources, although some of the witnesses are cited in other texts. ${ }^{16}$ Ahuni's name does occur in Larsa, attached to an official just after the Babylonian conquest (H36-Si7). ${ }^{17}$ But I have not succeeded in locating a homonym whose father was an Ilšu-ibbi. Šat-Marduk's name was comparatively uncommon. ${ }^{18}$ To judge from Sommerfeld's listing,

15. As noted by Gurney (Zikir šumim, 93-94), "[Ilatu] is neither thrown in the river and drowned, as in $\mathrm{Ai} 7$ iv 1-7, hurled from a tower, nor sold as a slave...; she is not even brought before the bäbtum as in $\mathrm{CH} \S 142 . "$

16. Anbar, "Textes," 125-26. Marten Stol writes me (1/25/2000): "I have no opinion about the many authorities who are witnesses. The two in lines 28-29 are a 'pair,' also attested in Stol, JCS 34 (1982): 177 no. 40:4-6 (with p. 185a Ili-ippalsam, 190a Šamaš-magir). In Riftin 32:12-16 these witnesses: Kalumum, son of Ubar-Šamaš; $\mathrm{Nu-x-tum} \mathrm{sanga;} \mathrm{Samaš-magir,} \mathrm{son} \mathrm{of} \mathrm{Qulalum;} \mathrm{Nur-}$ Ištar, son of Șilli-Šamaš; Ili-ippalsa (last witness, no father's name). Samsu-iluna year 5.'

17. D. Arnaud, "Larsa. Catalogue des textes et des objets inscrits trouvés au cours de la sixième campagne," Syria 56 (1976): 66-67; TCL 11 212:15, coll. Arnaud, RA 70 (1976): 91 (ref. courtesy M. Stol). Kutalla has left us a small dossier belonging to an Ahuni son of Ubaya: see D. Charpin, Archives familiales et propriété privée en Babylonie ancienne. Étude des Documents de 'Tell Sifr' (Geneva, 1980), 135-37. The name Ahuni does not seem to be common in Sippar, but for its presence in nearby Halhalla, see M. Stol, "Die altbabylonische Stadt Halhalla," in dubsar anta-men. Studien zur Altorientalistik. Festschrift für Willem H. Ph. Römer zur Vollendung seines 70. Lebensjahres mit Beiträgen von Freunden, Schülern und Kollegen, ed. M. Dietrich and O. Loretz (Münster, 1998), 439.

18. Struck by finding a Marduk name at Larsa less than two decades after Hammurabi's conquest of the city, Marten Stol wonders whether its bearer had moved there from Babylon. (Private communication, $1 / 27 / 2000$.) 
the name she bore gives us no clue as to her marital status or her profession, for it was held by married ( $A b B 195 ;$ VS 737 ) as well as unmarried women (likely in CT $813 \mathrm{c}$, YOS 12469 , and MHET 2/2 200:7 [transfer of property]; not clear in VS 7315 ). ${ }^{19}$ Was she, for example, a naditu of Marduk? ${ }^{20}$ Yet we notice that the case of Sat-Marduk and Ahuni was not particularly private, for their oaths attracted a whole bevy of elite witnesses.

Of the two opponents, Ahuni alone is given a patronymic and this could suggest that he was still under parental control. Roth is alert to this phenomenon and wonders whether the document implies interference on the part of Ahuni's father (or family) to the issue of forcing the two apart. She also wonders whether Šat-Marduk was a slave, possibly because of the coinage of her name. ${ }^{21} \mathrm{I}$ am also struck by the fact that Sat-Marduk is linked to no one, male or female, thus suggesting an independence from male protection. Such a condition for women may not have been that uncommon in real life, even if it is not clearly displayed in legal compilations. ${ }^{22}$ This is not surprising, for we must keep in mind that while legal compilations can indeed be windows to the world of antiquity, they are not encyclopedic about social relations and certainly not always realistic about the conditions they are said to regulate. ${ }^{23}$

Šat-Marduk may well have been a prostitute, as Westbrook suggests. But assigning her this profession will not enlighten us too much as long as we do not know what kind of people became prostitutes, what kind of lives they led, or their status in their local society. Solving such questions has not proven easy-witness the spate of recent articles on prostitution, complicated by the distinctions that are generally proposed between profane and sacred (or sacral)

19. W. Sommerfeld, Die Aufstieg Marduks (Neukirchen-Vluyn, 1982), 141 n. 1.

20. A Šat-Marduk is known as a naditum of Marduk and Sarpanitum; see Abdullah Amin Agha, "The Site of Usiyeh," Supplement to Sumer 45 (1987-88 [1996]): 52 (English, 120). (Reference courtesy of M. Stol.) Whether a naditu was a prostitute (sacred or profane) has been debated in the literature. Most scholars do not think so and some speak of all but those attached to Marduk as "virgins"; Elizabeth C. Stone, "The Social Role of the naditu women in Old Babylonian Nippur," JESHO 25 (1982): 55-56; Ulla Jeyes, "The Naditu Women of Sippar," in Images of Women in Antiquity, ed. A. Cameron and A. Kuhrt (Detroit, 1983), 260-72. But see W. Lambert, "Prostitution," in Außenseiter und Randgruppen, ed. V. Haas (Konstanz, 1992), 137-38 and 154-55 n.18. The hard evidence is given succinctly in $\mathbf{M}$. Stol's richly informative "Women in Mesopotamia," JESHO 38 (1995): 138-39.

21. "'She Will Die by the Iron Dagger," 193 n. 14.

22. For this reason, I do not think that an Ur-Namma adultery provision is at stake. In Roth's rendering (Law Collections, 17-18), LU paragraph 7 reads, "If the wife of a young man, on her own initiative, approaches a man and initiates sexual relations with him, they shall kill that woman [var. The man shall kill that woman]; that male shall be released." We notice too that the punishment is much more categorical in this instance than what obtains in Sat-Marduk's case.

23. In fact, as has been observed by many scholars, the best views these legal formulations provide are not of the workings of Mesopotamian society, but rather of rulers with divinely sanctioned authority to dispense justice, regulate relationships, or establish order. They might also best illustrate the propensity of intellectual scribes to categorize human behavior. 
prostitution. Bottéro has written a charming article in which he makes prostitutes free to love if not also lovers of freedom. ${ }^{24}$ But even if we are not swayed by his argument, we must take seriously recent proposals not to stigmatize the behavior of sexually available women on the basis of failings not evident in their own cultures. ${ }^{25}$ If we espouse such caution, it follows then that any interpretation of a legal formulation or a juridical document that mentions prostitutes would be more convincing when not guided by our contemporary sense of morality.

Again, Sat-Marduk may have been a prostitute. Yet we should dwell not on the presumed unsavory nature of her life but, with Lambert, imagine that far from belonging to a segment of society managed and controlled by law, she may have achieved a form of independence from male stewardship and been left to her own devices for survival. ${ }^{26}$ It would be useful to add, however, that this category of autonomous women likely included well-to-do widows, ${ }^{27} \mathrm{di}$ vorced women, and unmarried daughters bereft of parents and of mature male siblings. Ignored by legal compilations were other women, such as dancers, performers, and healers, whose livelihood forced them to move among a number of locales, thus weakening their attachment to any one political entity. ${ }^{28}$

24. J. Bottéro, “'Free Love' and Its Disadvantages," Mesopotamia. Writing, Reasoning, and the Gods (Chicago, 1992), 185-98.

25. See Norman Yoffee, "The Economics of Ritual at Late Old Babylonian Kish," JESHO 41 (1998): 312-43 (with excellent bibliography), who studies the Old Babylonian kezertu and warns against stigmatizing through shallow acquaintance with institutional contexts. See also the skepticism expressed by Joan Goodnick Westenholz, "Tamar, qdša, qadištu, and Sacred Prostitution in Mesopotamia," Harvard Theological Review 82 (1989): 245-65; "Heilige Hochzeit und kultische Prostitution im alten Mesopotamien. Sexuelle Vereinbarung im sakrale Raum?" Wort und Dienst. Jahrbuch der Kirchlichen Hochschule Bethel 23 (1995): 43-62. Julia Assante gives away her position on the matter in the title of her stimulating albeit categorical article, "The kar.kid / harimtu, Prostitute or Single Woman? A Reconsideration of the Evidence," UF 30 (1998): 5-96. She distinguishes between the "sexy" harimtu of literature and the unattached and independent woman who is so labeled.

26. Lambert, "Prostitution," 133-34: "The question with prostitutes is whether they could exist as free, independent women, practicing their profession and not even legally under a male relative. In the lack of plain, authoritative answers to this question one may say from a legal standpoint this probably could not happen, but in actual life it often happened with prostitutes." See also G. Wilhelm, "Marginalien zu Herodot Klio 199," in Lingering over Words. Studies in Ancient Near Eastern Literature in Honor of William L. Moran, ed. Tzvi Abusch et al. (Atlanta, 1990), 505-24.

27. In our sense, whether or not almattum refers to their independence, so not necessarily paradigmatic for vulnerability and indigence. On widows, see M. Roth, "The Neo-Babylonian Widow," JCS 43-45 (1991-93): 1-26 (bibliography in notes to pp. 1-2). Roth correctly shows how the term needs to be interpreted locally and that the legal status of a particular widow was by no means constant even within a specific culture. See also Stol, "Women," 132-33 (on widows), 130-31 (on divorcees); Th. Kämmerer, "Zur sozialen Stellung der Frau in Emār und Ekalte als Witwe und Waise," UF 26 (1994): 169-208.

28. In her "Independent Woman in Ancient Mesopotamia," Rivkah Harris evaluated and confirmed this possibility of such ways of life, although for her evidence she gravitated toward the world of the prostitute and the naditu; in Women's Earliest Records from Ancient Egypt and 
Encouraged by the lack of males attached to Sat-Marduk, let me hypothesize that, whatever her profession and for reasons that escape us, Šat-Marduk was on her own. On 25.vi[Elïlu].Si3 she went to the Ebabbar temple of Shamash in Larsa and took an oath that consists of assertions, exculpations, and promises. Among those witnessing her testimony were the governor of Larsa, a temple elite, a head seal-cutter, and a host of luminaries, some of whom chose to confirm their presence by rolling inherited seals on the document. Sat-Marduk opened with purgatory oaths, by which she meant to clear herself from assumptions, charges, or suspicions. In using stative verbal forms, she affirmed that at the time of oath-taking Ahuni was not under her control physically (la kalâkšu). Furthermore, because she did not then have him under commitment (la tummakšumma), Ahuni was under no compulsion to return to her. By these oaths, Sat-Marduk clearly sought to shift the onus onto Ahuni. Were he ever in her presence, it would be because he chose to be and not because she had power over him.

The next series of statements looks toward the future. While it may seem incongruent that Sat-Marduk would commit to activities that are Ahuni's to undertake ("He must not talk to me about sexual intimacy, he must not kiss my lips"), in fact by this application of a decisory oath she was referring any decision of the matter to an oath that Ahuni would be made to take. ${ }^{29}$ SatMarduk was thus making certain that Ahuni would be binding himself never to be intimate with her; but she was also declaring her reluctance to listen to any potential advances on his part: she would not be titillated by the promise of love-making, she would not be engaged in foreplay. ${ }^{30}$ Moreover, she

Western Asia, ed. Barbara S. Lesko (Atlanta, 1989), 145-56. Similar thoughts are expressed by I. M. Diakonoff, "Women in Old Babylonia not under Patriarchal Authority," JESHO 29 (1986): 225-38, reformulated in "Old Babylonian Ur," JESHO 38 (1995): 92-93.

29. I quote from H. C. Black, Black's Law Dictionary, 5th ed. (St. Paul, Minn., 1979), 966: "Decisive or decisory oath. In the civil law, where one of the parties to a suit, not being able to prove his charge, offered to refer the decision of the cause to the oath of his adversary, which the adversary was bound to accept, to tender the same proposal back again, otherwise the whole was taken as confessed by him."

30. Among the MEs Enki handed over to Inanna were those for "love making, kissing, prostitution ..."; see Gertrud Farber, "Inanna and Enki," CoS I, 523 (col B, VII).

There is deliciously malicious gossip in a letter sent to King Zimri-Lim of Mari that implies that along with manipulating genitals, "kissing the lips" was one step removed from sexual consummation ( $A R M 26488: 29-41$; see also the lexical segment of the CAD article našăqu): Buqaqum reports on three matters to Zimri-Lim. The first has to do with a meeting between Hammurabi (Babylon) and Ibal-pi-El, head of ZL's military contribution to the war against Larsa. The second deals with the movement of Eshnunna troops near Tuttub. The third is as follows (29-41):

The wife of Sin-iddinam has made the following attestation: "Before Sin-iddinam could marry me, I agreed with father and son, so that whenever Sin-iddinam left his home, the son of Asqudum would notify me, 'I want to have you!' He kissed my lips and touched 
herself would never invite his attentions. By this promise, Sat-Marduk documented her readiness not to pursue a relationship with Ahuni.

The heart of Šat-Marduk's case is found in the next set of affirmations, for through them she was empowering a third party to enforce the distancing she was seeking from Ahuni. There cannot be any sexual relations between her and Ahuni, and if he beguiled her ("should he summon me to sleep with him") she would report it to the town's authority (the elders and the rabianum). It is crucial to recognize that the appeal to the authorities is not (to quote Westbrook) because Šat-Marduk "is being called upon to police the enforcement of the prohibition," and certainly not because "she is obviously someone with whom the authorities have sufficient leverage to be able to force her to act on matters of utmost intimacy - a position that one can readily ascribe to a public prostitute." 31 (In fact, in Larsa and its environs, the participation of the rabiannum and the town's elders seems investigative and constabulary rather than for purposes of enforcement. ${ }^{32}$ ) Rather, it is because by pledging to report Ahuni's sexual propositions to the authorities (who may or may not include those named as witnesses), Šat-Marduk was making certain that the man would be fully investigated for violating his oath. This threat was Šat-Marduk's best hope to thwart Ahuni's unwelcome advances.

It is reasonable, but by no means crucial, to suppose that Šat-Marduk was aware that she was maneuvering Ahuni into taking an oath, even to the extent of suggesting its phrasing. It is also not beyond likelihood, given Sat-Marduk's earlier affirmations, that Ahuni was not a stranger to her. Perhaps she was trying to put to end a relationship gone sour. At any rate, Ahuni's own oath ("II swear that] I will not go to Šat-Marduk and [that] I

my vagina; but his penis did not penetrate my vagina, for I thought, I will not $\sin$ so contemptibly against Sin-iddinam. I have not done in my own house what is not done (to?) my husband ..." They [made her plunge (as ordeal)], and she survived it ...

Sophie Lafont has many good comments to make about this text, although she (wrongly, in my opinion) assigns the hanky-panky to an interval between engagement and marriage; see Femmes Droit et Justice, 56-59, 248, 268-69, 284-86, 498-99 [text citation]. If so, the woman's excuse (if not also the maliciousness of the gossip) loses much of its irony. Note too that the dalliance was taking place when Sin-iddinam (also called bèlum) was not at home, hardly an important detail had it occurred before their marriage. It is interesting to note that Y. Sefati finds testimony in a Sumerian love song that an oath of chastity preceded the kissing of the lips and touching of the genitals; see his "An Oath of Chastity in a Sumerian Love Song (SRT 31)?," in Bar-llan Studies in Assyriology Dedicated to Pinhas Artzi, ed. J. Klein and A. Skaist (Tel-Aviv, 1990), 53 (lines 17-26), 59-60.

In another Mari text (ARM 13 101:19-20) a man kisses the lips of his future son-in-law, to symbolize an agreement. On this text, see the collations and comments of J.-M. Durand, "Relectures d'ARMT XIII, II; La correspondance de Numušda-narânî," MARI 2 (1983): 101-2.

31. Westbrook, "Enforcement of Morals," 755.

32. See Charpin, Archives familiales, 193-94; Arnaud, "Larsa," 75. 
will not talk to her about sexual intimacy," 11. 19-21) repeated only half of the formula Sat-Marduk had wished him to invoke ("He must not talk to me about sexual intimacy, he must not kiss my lips"). Yet, terse though it may have been, his pledge was couched in the first-person, using verbs that exhibit Ahuni's capacity to make choices: He would not go to the woman; he would not speak to her. ${ }^{33}$ This language is in marked contrast to Šat-Marduk's longer vows where she displayed her own will only when impelled to react to Ahuni's potential overtures (1.9), or when she felt forced to expose his crude solicitation (1. 12).

If through her pledge to expose Ahuni, Sat-Marduk had turned the town's officials into defenders of her wish not be harassed, her last statement ("If I am found with him [or: in the countryside], I should be treated as if I broke an oath by the king") brought her back to the spirit of her opening remarks, in which she implied that it would be no fault of hers were Ahuni to approach her. Here, too, she gingerly resisted any implication of willing participation in a potential encounter with Ahuni by turning to verbal constructions in the third-person plural with indefinite subjects. Elusive is the sense of ina ahätim in this context, Anbar translates it "dans les environs," implying that where Sat-Marduk and Ahuni get caught-in this case beyond the town's confineswould be a major reason to suppose that she had contravened an oath. But such a meaning would be more likely had ahûm been in the plural (ina ahiātim/ ahâtim). Westbrook has "in (his) company," suggesting that Šat-Marduk had sought out Ahuni. But this rendering would be more certain had a possessive pronoun (ina ahātišsu) been suffixed to ahătim. ${ }^{34}$ The dictionaries give exceptional usages for each of the above, making it difficult to settle the issue philologically. The main intent of the clause, however, remains that of conveying Sat-Marduk's certitude that no circumstance would ever find her a willing participant in a dalliance with Ahuni.

What do we make of all this? I have argued that whatever its exact intent, LL 30 cannot be used to illumine the two juridical documents discussed above. In the case of BM 13192, a reading of its contents has led me to recreate a situation in which an independent woman from Larsa of the Old Babylonian period had found a way to restrain a man from harassing her sexually by legally setting the whole town between them. How Šat-Marduk achieved this independence is lost to us, but our text makes it obvious that she had legal recourse to maintain it. That in our document both parties are eventually

33. Akkadian ana sinništim aläkum can mean "to have intercourse with a woman," but given its sequence in this oath, it is best to be literal about the use of the verb.

34. There are exceptions to each of the above, ina ahătim minus a possessive suffix but with the meaning "in (one's) circles" is found in $F M 2$ 120:5; AbB 9 175:8-9. Not as manifest are examples of singular ina ahātim with the meaning "countryside," see CAD A/1, 190 (4a). 
deposed may mean that we are not dealing with the partial record of a trial with plaintiffs and defendants, but with that of a hearing in which oaths established potential injury-eventually resulting in an injunction preventing Ahuni from harassing Sat-Marduk. ${ }^{35} \mathrm{I}$ also admit that I cannot establish what in those days constituted sexual harassment, for the rub has always been that cultures maintain different and often contradictory thresholds on how to judge sexual aggression. ${ }^{36}$ Still, if there is a moral I would like to see enforced at this juncture, it would be that by resisting the urge to interpret juridical documents through the available legal formulations we might achieve a richer vision of complexity and diversity among the populations of ancient Mesopotamia.

35. In tannaitic literature only defendants take oaths. See E. E. Hallewi, “The Oath (A Chapter in the History of the Halakha)," Tarbiz 37 (1967): 24-29.

36. In the classical period, respectable women were unapproachable, their status recognized through the type of dress they wore and (as in Assyria) by the veil that covered their heads. A woman who failed to display a proper appearance deserved blame were she ever accosted; see Thomas A. J. McGinn, Prostitution, Sexuality, and the Law in Ancient Rome (New York, 1998), 331-35. 